composed of 15 ABBA sequences of counterbalanced 30 -sec periods. A barpress during one 30-sec period produced the stimulus; a barpress during the other period did not.

\section{Results and Discussion}

Group HT-SR received an average of 22.3 N-R transitions per day, each following an $\mathrm{N}$-length that averaged 1.1 nonreinforcements. The corresponding averages in Group LT-LR were 2.6 and 10.1. The Day 7 mean latencies for each $S$ on trials following a reinforced stimulus presentation (post-SR latency) and on trials following a nonreinforced stimulus presentation (post-no-SR latency) provided the basic data. However, the within-cell variances were not homogeneous $\left(\mathrm{F}_{\mathrm{max}}=39.11, \mathrm{p}<.01\right)$; thus, the Mann-Whitney $U$ test and the Wilcoxon matched-pairs signed-ranks test ${ }^{2}$ (Siegel, 1956) were used in the data analysis. The mean post-SR and post-no-SR latencies of Group HT-SR were $1.52 \mathrm{sec}$ and $1.18 \mathrm{sec}$, respectively $(T=5, p<.05)$. The mean post-SR and post-no-SR latencies of Group LT-LR were $1.50 \mathrm{sec}$ and $3.36 \mathrm{sec}$, respectively $(T=1, p<.01)$. The significant differences between the post-SR and post-no-SR latencies for $S s$ in both groups indicated that each reinforcement schedule was discriminated. That is, Ss responded more quickly on trials with a $90 \%$ reinforcement probability than they did on trials with a $10 \%$ reinforcement probability. Thus, the presence or absence of reinforcement on a given trial became a discriminative stimulus that controlled behavior on the following trial. The post-SR latencies of the two groups were not significantly different $(U=32$, $\mathrm{p}>.50)$; however, the post-no-SR latencies were significantly shorter in Group HT-SR than in Group LT-LR ( $U=0, p<.001)$. The latencies for the two groups on trials with a $90 \%$ reinforcement probability (HT-SR post-no-SR and LT-LR post-SR) were not significantly different $(U=15$, p > .05); however, on trials with a $10 \%$ reinforcement probability (HT-SR post-SR and LT-LR post-no-SR), the Group HT-SR latencies were significantly shorter than the Group LT-LR latencies $(\mathrm{U}=1, \mathrm{p}<.001)$.

The mean number of extinction responses emitted during the stimulus period and during the no-stimulus period were 120.7 and 93.1, respectively $(\mathrm{F}=10.10, \mathrm{df}=1 / 14, \mathrm{p}<.01)$. This difference indicated that the stimulus had become a conditioned reinforcer $\left(\mathbf{S}^{\mathbf{r}}\right)$. That is, the stimulus increased resistance to extinction in both groups. The mean number of extinction responses emitted by Group HT-SR and by Group LT-LR were 96.0 and 117.8 , respectively $(F=1.19$, $\mathrm{df}=1 / 14, \mathrm{p}>.25)$. The Extinction Periods by Groups interaction was not significant $(F=1.02, \mathrm{df}=1 / 14, \mathrm{p}>.25)$, indicating that the pattern of reinforcement affected neither response strength nor $S^{r}$ strength. The latter finding is consistent with the results of Experiment 1.

The negative findings with respect to the effect of schedule pattern on $S^{\mathbf{r}}$ strength may be explained in three alternative ways. First, reinforcement pattern has no effect on $\mathbf{S}^{r}$ strength. Second, if both N-length and number of N-R transitions affect $S^{r}$ strength, the effects of one variable may have cancelled the effects of the other since high transition probability was associated with short $\mathrm{N}$-length, and vice versa. Third, Koteskey \& Stettner (1968) have suggested that the PRE effect is either absent or greatly reduced in situations where the reinforcement schedule is discriminated. The findings of the present study that reinforcement pattern had no effect on resistance to extinction supports this suggestion since the patterns were discriminated. The same explanation may apply to the negative finding with respect to $\mathbf{S}^{\mathbf{r}}$ strength. Research that eliminates pattern discrimination by the use of less extreme transition probabilities and which does not confound $\mathrm{N}$-length and number of $\mathrm{N}-\mathrm{R}$ transitions is indicated.

\section{REFERENCES}

AMSEL, A. The role of frustrative nonreward in noncontinuous reward situations. Psychological Bulletin, 1958, 55, 102-119.

CAPALDI, E. J. Effect of N-length, number of different N-lengths and number of reinforcements on resistance to extinction.
Journal of Experimental Psychology, 1964, 68, 230-239.

CAPALDI, E. J., \& STANLEY, L. R. Percentage of reward vs $\mathrm{N}$-length in the runway. Psychonomic Science, 1965, 3, 263-264.

GONZALEZ, R. C., \& BITTERMAN, M. E. Resistance to extinction in the rat as a function of percentage and distribution of reinforcement. Journal of Comparative \& Physiological Psychology, 1964, 58, 258-263.

KIMBLE, G. A. Hilgard and Marquis' conditioning and learning. New York: Appleton-Century-Crofts, 1961.

KOTESKEY, $R$. L. The effect of unreinforced-reinforced sequences on resistance to extinction following partial reinforcement. Psychonomic Science, 1969, $14,34 \& 36$.

KOTESKEY, R. L., \& STETTNER, L. J. Role of nonreinforcement-reinforcement sequences in the partial reinforcement effect. Journal of Experimental Psychology, 1968, 76, 198-205.

LAWRENCE, D. H., \& FESTINGER, L. Deterrents and reinforcement. Stanford: Stanford University Press, 1962.

MOWRER, O. H., \& JONES, H. Habit strength as a function of the pattern of reinforcement. Journal of Experimental Psychology, 1945, 35, 293-311.

SIEGEL, S. Nonparametric statistics. New York: McGraw-Hill, 1956.

SPIVEY, J. E., \& HESS, D. T. Effect of partial reinforcement trial sequences on extinction performance. Psychonomic Science, 1968, 10, 375-376.

SPIVEY, J. E., HESS, D. T., \& BLACK, D. Influence of partial reinforcement pattern and intertrial reinforcement on extinction performance following abbreviated training. Psychonomic Science, 1968, 10, 377-378. NOTES

1. The author thanks John C. Birkimer for his comments on this manuscript.

2. Significance levels for the Wilcoxon signed-ranks tests are one-tailed.

\title{
Effect of CS position reversal on extinction in shuttle air-blast avoidance
}

\author{
THOMAS W. BAKER and DONALD \\ ZIEGELBAUER, Lawrence University, \\ Appleton, Wis. 54911
}

Squirrel monkeys were trained to avoid an airblast in a two-way shuttle procedure. Following acquisition and after a 10-day rest, one group received 5 days of relearning, the other group received 2 days of relearning and 3 days of training with CS position reversed. Both groups were then extinguished to the $C S$ in its original position. The reversed group exhibited significantly greater resistance to extinction.
Recently, Polidora \& Boyer (1967) reported rapid and stable avoidance learning by squirrel monkeys using an airblast US. These findings were similar to those reported for rats (Ray, 1966a, b) and for cats (Ray, 1966c). McAdam (1964), using cats as Ss, found that avoidance learning was slower if the task required the $S$ to shuttle toward the CS rather than away from it. Whittleton, Kostanek, \& Sawrey (1965) extended these findings using rats as Ss and, in addition, showed that extinction was more rapid under the condition that required the $S$ to shuttle toward the CS. The present study attempted to assess the effects of a change 
in CS directionality during relearning and to measure the effect of this change on extinction of the original task.

\section{METHOD}

The Ss consisted of six adult squirrel monkeys that were assigned randomly to one of two groups. The Ss had previously been used in a discrimination experiment using positive reinforcers. None of the Ss had been exposed before to negative USs of any variety in an experimental setting.

The shuttlebox (12 $27 \times 19$ in. high) was modeled after that used by Polidora \& Boyer (1967). The walls, ceiling, and vertically sliding doors at either end were all constructed of 3/8-in. thick, translucent Plexiglas. The floor consisted of $1 / 4$-in. hardware cloth.

The US consisted of an airblast $\left(25 \mathrm{lb} /\right.$ in. $\left.^{2}\right)$ delivered through two $1 / 2$-in. pipes located parallel to and 1 in. from the floor and either end of the box. Each pipe contained 15 alternating 0.043 -in. holes, spaced 1.5 in. apart: 7 parallel to the floor, and 8 at a 20-deg angle with the floor. The CS consisted of a $71 / 2$-W bulb with reflector mounted on the outside of each door. The experimental room was almost totally dark when a CS was not in operation.

The CS-US interval was $5.0 \mathrm{sec}$. The ITI was varied nonsystematically by $E$ about an average interval of $30 \mathrm{sec}$. Shuttle responses were recorded by means of a photocell circuit. Interruption of the beam positioned midway in the box terminated CS on avoidance trials and both CS and US on nonavoidance trials.

All Ss received $10 \mathrm{~min}$ of adaptation to the box on their 1st day. Thereafter, all Ss received 10 trials per day. The two groups will be designated as RR (CS reversal in relearning) and as $R$ (no CS reversal in relearning).

All Ss were to receive 14 days of avoidance learning, consisting of shuttling from the side on which the CS appeared. Following avoidance learning, each $S$ received 10 days of rest (no testing), followed by either 5 days of relearning (Group R) or 2 days of relearning and 3 days of CS reversal (Group RR). The CS-reversal procedure consisted of presenting the CS on the side opposite to
S's location and to where the UCS would be presented given a failure to respond.

On the day following the 5 th day of relearning or relearning-reversal, all Ss commenced 10 days of extinction to the nonreversed CS, i.e., all Ss were extinguished to the response of running from the CS.

\section{RESULTS}

In all of the following analyses, $\mathrm{p}<.05$ has been adopted as the level of statistical significance.

\section{Avoidance Learning}

Both groups reached a $90 \%$ avoidance-response level by the end of 12 days. The groups did not differ either in the form of the acquisition process (Days by Groups, $F=1.26,11 / 44 \mathrm{df}$ ) or in the overall CR level attained $(F<1,1 / 4 \mathrm{df})$.

Relearning-Reversal

The Ss in Group RR, who received the CS reversal on Days 3-5 of the relearning-reversal period, did not differ in their overall 5-day average avoidance performance from Group $\mathrm{R}(\overline{\mathrm{X}} \mathrm{s}=91.33 \%$ and $92.00 \% \mathrm{CR}$, respectively). However, the Groups by Days interaction was significant $(F=4.63,4 / 16 \mathrm{df}, \mathrm{p}<.05)$, indicating a different pattern of performance across the 5-day period (cf. Fig. 1). There was no difference in the number of ITRs made during the period $(\mathrm{F}<1,1 / 4 \mathrm{df})$.

\section{Extinction}

It will be recalled that all Ss were extinguished to the $\mathrm{CS}$ in its original direction. Therefore, Group RR was reversed again in order to provide extinction on the original avoidance-learning task. Although the difference in the overall avoidance level between groups in extinction did not reach the accepted level of statistical significance $(\mathrm{F}=6.10,1 / 4 \mathrm{df}, \mathrm{p}<.10)$, the Groups by Days interaction was significant $(F=3.03$, 9/36 df, p <.01). A trend test for difference in linearity found the groups to differ in rate of extinction $(F=6.32$, $1 / 36 \mathrm{df}, \mathrm{p}<.05)$. These results indicate that Group R, which had not been reversed, extinguished at a faster rate than did Group RR, which had been reversed (cf. Fig. 1).

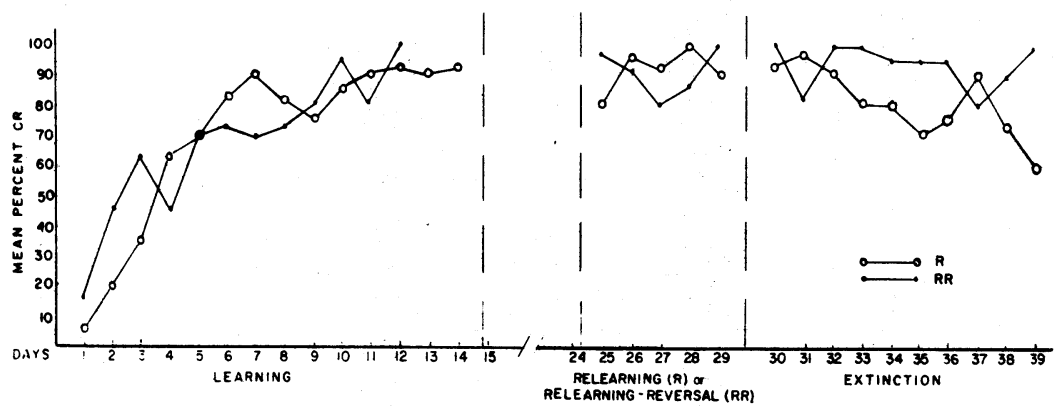

\section{DISCUSSION}

It appears that the decrement in avoidance learning produced by requiring the $S$ to shuttle toward the CS rather than away from it (McAdam, 1964; Whittleton et al, 1965) can be minimized by first training the $S$ on two-way avoidance. This is perhaps similar to the findings of Theios \& Dunaway (1964) which showed that two-way avoidance learning was more rapid if it followed one-way avoidance learning. The greater resistance to extinction shown by Group RR cannot be ascribed to differences between the groups in number of US presentations either in original learning or in relearning-reversal. Further, the direction of the difference in extinction is not easily handled by any of the contemporary formulations of avoidance learning (cf. Herrnstein, 1969). However, if one assumes, as did Thompson \& Spencer (1966), that common neural mechanisms subserve both extinction and habituation, then any procedure that retards habituation should also operate in a similar fashion with respect to extinction. The introduction of varying CS positions during learning would thus serve the function of stimulus change, with its resultant effect of extinction-habituation.

\section{REFERENCES}

HERNSTEIN, R. J. Method and theory in the study of avoidance. Psychological Review, 1969, 76, 49-69.

McADAM, D. Effects of positional relations between S, CS and US on shuttle box avoidance learning in cats. Journal of Comparative \& Physiological Psychology, 1964, 58, 302-304.

POLIDORA, V. J., \& BOYER, W. N. Avoidance learning by squirrel monkeys: Measures and motivators. Psychonomic Science, 1967, 7, 175-176.

RAY, JR., A. J. Shuttle avoidance: Rapid acquisition by rats to a pressurized air conditioned stimulus. Psychonomic Science, 1966a, 5, 29-30.

R A Y, JR., A. J. Nonincremental shuttle-avoidance acquisition to pressurized air US. Psychonomic Science, 1966b, 5, 433-434.

RAY, JR., A. J. Shuttle avoidance: An apparatus for cats utilizing an airblast unconditioned stimulus. Journal of Genetic Psychology, 1966c, 109, 131.

THEIOS, J., \& DUNAWAY, J. E. One-way versus shuttle avoidance conditioning. Psychonomic Science, 1964, 1, 251-252.

THOMPSON, R. F., \& SPENCER, W. A. Habituation: A model phenomenon for the study of neuronal substrates of behavior. Psychological Review, 1966, 73, 16-43.

WHITTLETON, J. C., KOSTANEK, D. J., \& SAWREY, J. K. CS directionality and intensity in avoidance learning and extinction. Psychonomic Science, 1965, 3, 415-416.

Fig. 1. Mean per cent $\mathrm{CR}$ in acquisition (Days 1-14), relearning or relearning-reversal (25-29), and extinction (30-39) as a function of blocks of 10 trials. 